\title{
KEMAMPUAN KELUARGA MERAWAT USIA LANJUT BERDASARKAN KARAKTERISTIK KELUARGA DAN USIA LANJUT
}

\author{
Siti Nur Kholifah ${ }^{1,2^{*}}$, Krisna Yetti ${ }^{3}$, Besral $^{4}$ \\ 1. Program Studi D3 Keperawatan Poltekkes Kemenkes Surabaya, Jawa Timur 60282, Indonesia \\ 2. Program Studi Magister Fakultas Ilmu Keperawatan Universitas Indonesia, Depok 16424, Indonesia \\ 3. Fakultas Ilmu Keperawatan Universitas Indonesia, Depok 16424, Indonesia \\ 4. Fakultas Kesehatan Masyarakat Universitas Indonesia, Depok 16424, Indonesia \\ *Email:kholifah_stp@yahoo.co.id
}

\begin{abstract}
Abstrak
Sebuah kecamatan di Kabupaten Sidoarjo, Jawa Timur mempunyai banyak usia lanjut. Tetapi belum diketahui kemampuan keluarga merawat usia lanjut. Penelitian analitik observasional ini bertujuan mengetahui hubungan karakteristik keluarga dan usia lanjut dengan kemampuan keluarga merawat usia lanjut. Populasi penelitian adalah keluarga dengan usia lanjut, jumlah sampel sebanyak 319 keluarga yang ditentukan dengan two stage cluster sampling. Hasil penelitian menunjukkan 48,3\% keluarga mampu merawat usia lanjut. Sub variabel yang paling dominan berhubungan dengan kemampuan keluarga yaitu sikap keluarga. Selanjutnya, perlu pengembangan Posyandu Usia Lanjut dengan melibatkan keluarga dan pembentukan paguyuban keluarga dengan usia lanjut. Penelitian dengan jenis action research tentang model perawatan usia lanjut yang mengaplikasikan keperawatan transkultural sebagai kerangka konsep penelitian perlu dilakukan.
\end{abstract}

Kata kunci: karakteristik keluarga, karakteristik usia lanjut, kemampuan keluarga merawat usia lanjut di rumah

\begin{abstract}
Most elderly in Sidoarjo Distric-East Java lives in a sub district. However, no evidence found about the family's ability to care of elderly people at home. This analytical-observational research attempted to identify the relationship between the characteristics of family and the elderly with the family's ability caring for the elderly at home. Research were elderly, the sample was 319 family selected by two stages cluster sampling. Result of research showed 48,3\% family able to take care of elderly at home. The most dominant sub variable related to family's ability was the family attitude to take care of the elderly. It was recommended to develop the Elderly Integrated Health Service and local community group by involving family with elderly. Furthermore, action researchs that apply transcultural nursing framework are needed to develop elderly care model.
\end{abstract}

Keywords: family's characteristics, elderly's characteristics, family's ability to take care of elderly at home

\section{Pendahuluan}

Peningkatan umur harapan hidup akan berdampak pada meningkatnya jumlah populasi usia lanjut. Pada 2010, penduduk usia lanjut diperkirakan 9,77\% dari total penduduk (Depkes RI, 2005), sehingga abad 21 akan menjadi 'Era Usia Lanjut' (Sirait \& Riyadina, 1999; Riasmini, 2002). Keluarga merupakan masyarakat yang paling dekat dengan usia lanjut (Wiarsih, 1999). Alasan keluarga untuk menerima usia lanjut sebagian besar (86,1\%) adalah karena tanggung jawab (Jang, et al., 2002, dalam Miller, 2004). Oleh karenanya, kemampuan keluarga merawat usia lanjut sangat penting untuk menjaga kesehatan dan kesejahteraan usia lanjut.
Kemampuan keluarga dalam merawat usia lanjut di rumah diartikan sebagai kemampuan keluar ga dalam melakukan tindakan untuk memenuhi kebutuhan fisik, psikologis, sosial, dan spiritual pada usia lanjut (Miller, 2004; Friedman, Bowden, \& Jones, 2003; Kuntjoro, 2002).Kemampuan keluarga ini dipengaruhi oleh beberapa faktor yang berasal dari keluarga dan faktor usia lanjut sendiri.

Teori yang digunakan sebagai dasar dari kemampuan keluarga dalam melakukan tindakan pada penelitian ini adalah teori dari Green (1984). Disebutkan bahwa perilaku seseorang terbentuk dari 3 (tiga) faktor yaitu predisposisi, pendukung, dan pendorong. 
Faktor predisposisi kemampuan keluarga bersumber dari karakteristik keluarga dan usia lanjut. Faktor pendukung adalah ketersediaan sarana dan prasarana, misalnya sarana transportasi, ruang keluarga, ruang ibadah, dan kamar tersendiri untuk usia lanjut. Faktor pendorong adalah sikap dari masyarakat dan petugas kesehatan terhadap perawatan usia lanjut.

Peneliti ini perlu dilakukan di sebuah Kecamatan di Sidoarjo Jawa Timur karena persentase usia lanjut di daerah tersebut adalah 8,03\% dari keseluruhan penduduk. Angka ini melebihi persentase skala nasional (7,4\%) (Dinkes Kab. Sidoarjo, 2004). Wilayah ini merupakan salah satu kecamatan di Sidoarjo, yang berupa daerah rural tetapi tengah berkembang menjadi daerah urban. Terbukanya pemukiman baru dan berbagai industri memungkinkan masuknya berbagai pengaruh yang dibawa oleh para pendatang.

Jumlah usia lanjut di wilayah tersebut adalah 1133 orang dan mayoritas (90\%) tinggal bersama keluarga. Akan tetapi, belum diperoleh data bagaimana kemampuan keluarga dalam merawat usia lanjut di rumah dan bagaimana kualitas kesehatan para usia lanjut dalam keluarga. Oleh karena itu, penelitian ini bertujuan mengetahui hubungan antara karakteristik keluarga dan karakteristik usia lanjut dengan kemampuan keluarga dalam merawat usia lanjut di wilayah tersebut.

\section{Metode}

Penelitian ini menggunakan desain analitik observasional dengan pendekatan cross-sectional. Jumlah populasi 1020 keluarga. Berdasarkan perhitungan, diperoleh sampel sebanyak 319 keluarga. Pemilihan sampel dengan two stage cluster sampling. Kriteria sampel adalah keluarga yang merupakan anak dari usia lanjut dan tinggal bersama serta bersedia menjadi responden.

Pengumpul data dibagi empat kelompok, masingmasing kelompok dua orang. Satu kelompok bertanggung jawab untuk 6 kelurahan. Satu orang mengambil data keluarga dengan menggunakan kuesioner. Sebelum mengumpulkan data, keluarga yang telah memenuhi kriteria diberi penjelasan tentang penelitian yang akan dilakukan. Apabila keluarga telah memahami penjelasan tersebut dan bersedia menjadi responden, keluarga menandatangani informed consent yang disediakan.

\section{Hasil}

\section{Kemampuan Keluarga Merawat Usia Lanjut di Rumah}

Hasil penelitian menunjukkan bahwa sebanyak 48,3\% keluarga termasuk kategori mampu merawat dan $51,7 \%$ termasuk tidak mampu merawat usia lanjut di rumah.

\section{Karakteristik Keluarga}

Hasil penelitian untuk karakteristik keluarga secara rinci terlihat pada tabel 1. Skor fasilitas dalam keluarga merupakan skala rasio berdasarkan hasil observasi.

\section{Karakteristik Usia Lanjut}

Hasil penelitian mendapatkan bahwa sebagian besar responden berusia lanjut $(70,2 \%)$ berumur 60-74 tahun. Sebagian besar $(88,4 \%)$ responden tidak bekerja dan $60,8 \%$ dalam keadaan sehat.

\section{Hubungan Karakteristik Keluarga dengan Kemampuan Keluarga Merawat Usia Lanjut di Rumah}

\section{Hubungan status ekonomi dengan kemampuan keluarga merawat usia lanjut di rumah}

Hasil penelitian menunjukkan dari 79 responden yang berstatus ekonomi sangat rendah, 38\% mampu merawat usia lanjut di rumah. Sebanyak 85 responden berstatus ekonomi rendah, 44,7\% mampu merawat usia lanjut. Sejumlah 76 responden berstatus ekonomi sedang, 50\% mampu merawat usia lanjut di rumah. Keluarga yang berstatus ekonomi tinggi, 60,8\% mampu merawat usia lanjut di rumah. 
Hasil uji kai kuadrat menunjukkan bahwa ada hubungan yang bermakna antara status ekonomi dengan kemampuan keluarga merawat usia lanjut $(\alpha=0,05)$.

\section{Hubungan status pendidikan dengan kemampuan keluarga merawat usia lanjut di rumah}

Hasil analisis menunjukkan bahwa 121 orang responden tidak lulus SD dan bersekolah SD, dengan rincian 1 (satu) orang tidak lulus SD dan 120 orang bersekolah SD. Berdasarkan data tersebut, 51,2\% mampu merawat usia lanjut di rumah. Responden berpendidikan SMP dan SMA berjumlah 185 orang. Sejumlah 89 orang berpendidikan SMP, dan 96 orang berpendidikan SMA.

Berdasarkan data tesebut, 44,3\% mampu merawat usia lanjut di rumah. Sebanyak 13 responden yang telah lulus perguruan tinggi, 76,9\% mampu merawat usia lanjut di rumah. Hasil uji kai kuadrat diperoleh bahwa ada hubungan antara tingkat pendidikan dengan kemampuan keluarga merawat usia lanjut di rumah $(p=0,054, \alpha=0,05)$.

\section{Hubungan pekerjaan keluarga dengan kemampuan keluarga merawat usia lanjut di rumah}

Subvariabel pekerjaan dibagi tiga bagian yaitu, kategori pekerjaan keluarga, jenis pekerjaan suami, dan pekerjaan istri.

\section{Kategori keluarga yang bekerja}

Data yang diperoleh menunjukkan, suami-istri bekerja sejumlah 100 orang, 47\% mampu merawat usia lanjut di rumah. Responden yang suami saja bekerja mencari nafkah untuk keluarga, 47,8\% mampu merawat usia lanjut di rumah. Sedangkan dari 41 responden yang bekerja sendiri atau hanya istri yang bekerja, 58,3\% mampu merawat usia lanjut di rumah. Hasil uji kai kuadrat menggambarkan tidak ada hubungan antara kategori pekerjaan keluarga dengan kemampuan keluarga merawat usia lanjut di rumah $(p=0,756, \alpha=0,05)$.

\section{Jenis pekerjaan suami}

Tabulasi silang menunjukkan 12 keluarga yang suami tidak bekerja ternyata 58,3\% mampu merawat usia lanjut di rumah. Keluarga yang suaminya bekerja swasta tidak menetap 41,7\% mampu merawat usia lanjut di rumah. Seratus dua puluh delapan keluarga dengan suami yang bekerja swasta menetap, 50,8\% mampu merawat usia lanjut di rumah. Sedangkan 15 keluarga yang suaminya bekerja sebagai PNS/ABRI, 66,7\% mampu merawat usia lanjut di rumah. Hasil uji statistik dapat disimpul-kan bahwa pekerjaan suami tidak berhubungan dengan kemampuan keluarga merawat usia lanjut di rumah $(\alpha>0,05)$.

\section{Jenis pekerjaan istri}

Hubungan pekerjaan istri dengan kemampuan keluarga merawat usia lanjut di rumah mendapatkan 178 keluarga dengan istri yang tidak bekerja, 47,8\% mampu merawat usia lanjut di rumah. Istri/ janda/wanita tidak kawin yang bekerja swasta tidak menetap, 41,8\% tidak mampu me-rawat usia lanjut di rumah. Sebanyak 34 istri/ janda/ wanita tidak kawin dengan pekerjaan swasta menetap, 70,6\% mampu merawat usia lanjut di rumah.

Disamping itu, lima keluarga dengan istri/ janda/ wanita tidak kawin bekerja sebagai PNS, 60\% mampu merawat usia lanjut di rumah. Hasil uji kai kuadrat didapatkan berarti ada hubungan bermakna antara pekerjaan istri dengan kemampuan keluarga merawat usia lanjut di rumah $(\alpha<0,05)$.

\section{Hubungan jumlah beban tanggungan keluarga dengan kemampuan keluarga merawat usia lanjut di rumah}

Berdasar analisis bivariat disimpulkan responden yang mempunyai beban tanggungan antara satu sampai lima orang, 46,4\% mampu merawat usia lanjut di rumah. Sedangkan responden yang mempunyai beban tanggungan lebih dari lima orang dalam keluarga, 53,8\% mampu merawat usia lanjut di rumah. Hasil uji kai kuadrat dapatdisimpulkan tidak ada hubungan antara jumlah beban tanggungan keluarga dengan kemampuan keluarga merawat usia lanjut di rumah $(p=0,258, \alpha=0,05)$. 
Tabel 1. Distribusi responden berdasarkan karakteristik keluarga

\begin{tabular}{|c|c|c|}
\hline Karakteristik keluarga & Jumlah & Persentase \\
\hline \multicolumn{3}{|l|}{ Status ekonomi } \\
\hline a. Sangat Rendah & 79 & 24,8 \\
\hline b. Rendah & 85 & 26,6 \\
\hline c. Sedang & 76 & 23,8 \\
\hline d. Tinggi & 79 & 24,8 \\
\hline \multicolumn{3}{|l|}{ Pendidikan } \\
\hline a. Tidak lulus SD/SD & 121 & 37,9 \\
\hline b. SMP/SMA & 185 & 58 \\
\hline c. Perguruan Tinggi & 13 & 4,1 \\
\hline \multicolumn{3}{|l|}{ Pekerjaan } \\
\hline a. Kategori pekerjaan keluarga & 100 & 31,34 \\
\hline 1) Semuanya bekerja & 178 & 55,81 \\
\hline 2) Suami saja yang bekerja & 41 & 12,85 \\
\hline 3) Istri saja yang bekerja/bekerja sendiri (janda/tidak kawin) & & \\
\hline \multicolumn{3}{|l|}{ b. Pekerjaan suami } \\
\hline 1) Tidak bekerja & 12 & 4,08 \\
\hline 2) Swas ta tidak menetap & 139 & 47,28 \\
\hline 3) Swasta menetap & 128 & 43,54 \\
\hline 4) $\mathrm{PNS} / \mathrm{ABRI}$ & 15 & 5,10 \\
\hline \multicolumn{3}{|l|}{ c. Pekerjaan istri/janda/tidak kawin } \\
\hline \multicolumn{3}{|l|}{ 1) Tidak bekerja } \\
\hline 2) Swas ta tidak menetap & 178 & 56,51 \\
\hline 3) Swasta menetap & 98 & 31,11 \\
\hline \multirow[t]{2}{*}{ 4) PNS } & 34 & 10,79 \\
\hline & 5 & 1,59 \\
\hline \multicolumn{3}{|l|}{$\begin{array}{l}\text { Jumlah beban tanggungan keluarga } \\
\text { a. } 1-5 \text { orang }\end{array}$} \\
\hline \multirow[t]{2}{*}{ b. $>5$ orang } & 239 & 74,92 \\
\hline & 80 & 25,08 \\
\hline \multicolumn{3}{|l|}{$\begin{array}{l}\text { Pengetahuan keluarga terhadap perawatan lansia } \\
\text { a. Kurang }\end{array}$} \\
\hline b. Cukup & 2 & \\
\hline \multirow[t]{2}{*}{ c. Baik } & 164 & 0,6 \\
\hline & 153 & 51,4 \\
\hline Sikap terhadap perawatan lansia & & 48 \\
\hline \multicolumn{3}{|l|}{ a. Negatif } \\
\hline \multirow[t]{2}{*}{ b. Positif } & 195 & 61,1 \\
\hline & 124 & 38,9 \\
\hline \multicolumn{3}{|l|}{ Skor fasilitas dalam keluarga } \\
\hline a. $10-16$ & 153 & 47,9 \\
\hline b. $17-21$ & 166 & 52,1 \\
\hline
\end{tabular}

Hubungan pengetahuan dengan kemampuan keluarga merawat usia lanjut di rumah

Hasil penelitian menunjukkan bahwa responden yang mempunyai pengetahuan baik berjumlah 153 orang, sebanyak 55,6\% mampu merawat usia lanjut di rumah. Seratus enam puluh enam responden mempunyai pengetahuan cukup dan kurang. Responden yang mempunyai pengetahuan cukup berjumlah 64 orang, sedangkan responden mempunyai pengetahuan kurang yaitu dua orang. Berdasarkan data tersebut disimpulkan sebanyak 41,6\% mampu merawat usia lanjut. 
Hasil uji statistik kai kuadrat didapatkan hubungan bermakna antara pengetahuan keluarga tentang perawatan usia lanjut dengan kemampuan keluarga merawat usia lanjut di rumah $(p=0,017, \alpha=0,05)$.

\section{Hubungan sikap keluarga dengan kemampuan keluarga merawat usia lanjut di rumah}

Hasil analisis bivariat dari sikap keluarga dengan kemampuan keluarga merawat usia lanjut di rumah, memperlihatkan dari 124 responden yang bersikap positif, 65,3\% mampu merawat usia lanjut. Sedangkan dari 195 responden yang bersikap negatif, 37,4\% mampu merawat usia lanjut di rumah. Hasil uji statistik kai kudrat dapat diketahui adanya hubungan yang bermakna antara sikap keluarga terhadap perawatan usia lanjut dengan kemampuan keluarga merawat usia lanjut di rumah $(p=0,00, \alpha=0,05)$.

\section{Hubungan fasilitas keluarga dengan kemampuan keluarga merawat usia lanjut di rumah}

Hasil uji statistik menunjukkan bahwa fasilitas dalam keluarga tidak mempunyai hubungan secara bermakna dengan kemampuan keluarga merawat usia lanjut di rumah $(\alpha>0,05)$.

\section{Hubungan Karakteristik Usia Lanjut dengan Kemampuan Keluarga Merawat Usia Lanjut di Rumah}

Hubungan umur usia lanjut, status pekerjaan, dan status kesehatan dengan kemampuan keluarga merawat usia lanjut di rumah

Hasil analisis bivariat umur usia lanjut menunjukkan bahwa 224 responden yang mempunyai usia lanjut berumur 60-74 tahun, 52,7\% termasuk mampu merawat. Sebanyak 95 responden yang tinggal dengan usia lanjut berumur 75-100 tahun, $37,9 \%$ mampu merawat usia lanjut tersebut.

Hasil uji statistik yang telah dilakukan dapat disimpulkan bahwa ada hubungan yang bermakna antara umur usia lanjut dengan kemampuan keluarga merawat usia lanjut di rumah $(p=0,015$, $\alpha=0,05)$.
Hubungan status pekerjaan usia lanjut dengan kemampuan keluarga merawat usia lanjut di rumah

Hasil penelitian tentang hubungan status pekerjaan usia lanjut dengan kemampuan keluarga merawat usia lanjut di rumah. Usia lanjut yang bekerja 37 orang, sejumlah 45,9\% mempunyai keluarga yang mampu merawat. Usia lanjut dalam keluarga yang tidak bekerja 282 orang, 48,6\% mempunyai keluarga yang masuk pada kategori mampu untuk merawat. Hasil uji kai kuadrat disimpulkan bahwa tidak ada hubungan antara status pekerjaan usia lanjut dengan kemampuan keluarga merawat usia lanjut di rumah $(p=0,8993, \alpha=0,05)$.

\section{Hubungan status kesehatan usia lanjut dengan kemampuan keluarga merawat usia lanjut di rumah}

Hasil analisis bivariat status kesehatan memperlihatkan, 194 usia lanjut yang sehat, 53,1\% berada dalam keluarga yang mampu merawat. Sedangkan dari 125 usia lanjut yang sakit, 40,8\% hidup bersama keluarga yang juga mampu merawat. Uji kai kuadrat yang telah dilakukan memperlihatkan ada hubungan yang bermakna antara status kesehatan usia lanjut dengan kemampuan keluarga merawat usia lanjut di rumah $(p=0,042, \alpha=0,05)$.

\section{Pembahasan}

Ketidakmampuan keluarga merawat usia lanjut berdasarkan hasil penelitian disebabkan karena belum memahami kebutuhan usia lanjut secara komprehensif, baik fisik, psikologis, sosial dan spiritual. Meskipun terdapat keluarga yang telah memenuhi kebutuhan tersebut, mereka menjalankan kebiasaan tanpa mengetahui tujuan dari apa yang telah mereka lakukan.

Menurut Moreover, Fortinsky, dan Hathaway (1990, dalam, Lueckenotte, 2000), yang menyatakan bahwa keluarga membutuhkan pendidikan secara kontinyu atau berkelanjutan untuk melakukan perawatan pada usia lanjut. 
Menurut Depkes RI (2005), pemberian pendidikan kesehatan yang berkesinambungan pada keluarga dapat menumbuhkan sikap dan perilaku yang akan meningkatkan kemampuan keluarga dalam merawat usia lanjut.

Kebermaknaan hubungan antara pengetahuan dengan kemampuan keluarga merawat usia lanjut di rumah mendukung teori Green (1984) bahwa pengetahuan merupakan faktor predisposisi pada seseorang untuk melakukan tindakan. Selaras dengan pernyataan Wiarsih (1999) bahwa keluarga yang mengetahui dan memahami tentang cara merawat usia lanjut di rumah, akan dapat membahagiakan dan mensejahterakan usia lanjut di lingkungan keluarga.

Salah satu faktor yang berhubungan dengan kemampuan keluarga merawat usia lanjut adalah faktor ekonomi. Hasil penelitian ini mendukung teori yang dikemukakan oleh Miller (2004) bahwa ekonomi keluarga merupakan salah satu dukungan sosial yang penting diberikan pada usia lanjut karena terkait dengan pemberian pelayanan kesehatan.

Analisis uji regresi logistik menunjukkan adanya hubungan yang bermakna antara pendidikan keluarga dengan kemampuan keluarga merawat usia lanjut setelah dikontrol dengan status ekonomi, sikap keluarga dan umur usia lanjut. Teori yang mendukung hasil penelitian ini diantaranya menurut Friedman, Bowden, dan Jones (2003) yang menyatakan bahwa pendidikan keluarga berhubungan dengan status kesehatan, karena pendidikan akan membentuk pengetahuan dan pola perilaku seseorang terhadap kesehatan.

Selain itu, menurut Notoatmodjo (2005), status pendidikan keluarga merupakan salah satu input dalam proses terbentuknya suatu keluaran perilaku baru. Hal ini akan mempengaruhi kemampuan keluarga melakukan tindakan sesuai yang diharapkan.

Jumlah tanggungan keluarga tidak berhubungan dengan kemampuan keluarga merawat usia lanjut.
Hasil penelitian ini bertentangan dengan hasil penelitian Demartoto (2003), yang menyatakan bahwa banyaknya jumlah beban tanggungan keluarga mempengaruhi kemampuan keluarga dalam memberikan perawatan pada usia lanjut. Keluarga dapat memanfaatkan sumberdaya tersebut untuk meringankan bebannya dalam hal merawat usia lanjut di rumah. Sesuai teori WHO tentang perilaku yang menyebutkan bahwa sumber daya yang tersedia merupakan faktor pendukung bagi seseorang dalam melakukan tindakan (Notoatmodjo, 2005).

Sikap keluarga juga berhubungan dengan kemampuan keluarga. Hasil ini sesuai dengan penelitian Purwanto (2002) bahwa keluarga yang bersikap positif memberikan perawatan yang lebih baik pada usia lanjut, sebaliknya keluarga yang bersikap negatif, perawatan yang diberikan kurang baik. Hasil penelitian tersebut mendukung pernyataan Hardiwiyoto dan Tony (1999, dalam Sutarna, 2001) bahwa sikap keluarga terhadap kesehatan usia lanjut sangat menentukan keberhasilan perawatan. Sikap tersebut dapat negatif dan positif.

Variabel fasilitas keluarga tidak ber-hubungan dengan kemampuan keluarga. Hal ini tidak sesuai dengan hasil penelitian Erawati (2002) yang mengambarkan bahwa fasilitas keluarga berpengaruh terhadap perawatan yang diberikan kepada usia lanjut.

Hasil penelitian ini juga tidak mendukung teori yang dikemukakan oleh Miller (2004), bahwa fasilitas yang disediakan keluarga merupakan dukungan instrumental yang bermanfaat untuk pemeliharaan kesehatan pada usia lanjut. Peneliti berpendapat bahwa tidak adanya hubungan antara fasilitas keluarga dengan kemampuan berkaitan dengan kurangnya kemampuan keluarga dalam memanfaatkan fasilitas yang dimiliki secara optimal.

Variabel umur usia lanjut berhubungan dengan dukungan keluarga, hal ini mempunyai kaitan dengan kemampuan fungsional pada usia lanjut. 
Seiring bertambahnya usia, maka akan semakin menurun kemampuannya untuk memenuhi kebutuhan sehari-hari, sehingga ketergantungan terhadap keluarga semakin meningkat.

Hasil tersebut mendukung hasil penelitian dari Rustika dan Riyadina (2000) yang menggambarkan bahwa semakin tua umur seseorang maka akan berpengaruh terhadap kemampuannya dalam memenuhi kebutuhannya sehari-hari. Selain itu, hasil penelitian dari Yan Hao (1998) juga menyatakan bahwa tingkat ketergantungan usia lanjut dipengaruhi oleh umur.

Semakin tua usia maka semakin menurun status kesehatannya. Pernyataan ini sesuai dengan hasil penelitian ada hubungan antara status kesehatan dengan kemampuan keluarga merawat usia lanjut. Hal ini berkaitan dengan peningkatan beban yang ditanggung keluarga dan keterbatasan pengetahuan keluarga dalam merawat usia lanjut yang sakit. Kondisi ini mendukung pernyataan bahwa keluarga sebagai pemberi perawatan akan mempunyai beban yang berlebih pada saat usia lanjut mengidap suatu penyakit serta menimbulkan reaksi psikososial misalnya stres pada keluarga sebagai pemberi perawatan (Gallo, Reichel, \& Andersen, 1998; Stanley, Blair, \& Beare, 2005).

\section{Kesimpulan}

Penelitian ini memberikan gambaran 48,3\% keluarga mempunyai kemampuan merawat usia lanjut di rumah. Analisis bivariat menunjukkan adanya hubungan yang bermakna antara status ekonomi, pendidikan, pekerjaan istri, pengetahuan, sikap, umur usia lanjut dan status kesehatan usia lanjut dengan kemampuan keluarga merawat usia lanjut di rumah.

Akan tetapi, tidak ada hubungan yang bermakna antara jumlah beban tanggungan keluarga, fasilitas keluarga, dan status pekerjaan usia lanjut dengan kemampuan keluarga merawat usia lanjut di rumah. Hasil analisis multivariat mendapatkan subvariabel yang paling dominan berhubungan dengan kemampuan keluarga tersebut adalah sikap keluarga terhadap perawatan usia lanjut setelah dikontrol dengan status ekonomi, pendidikan keluarga dan umur usia lanjut.

Berdasarkan hasil penelitian ini, perlu pembentukan paguyuban keluarga dengan usia lanjut untuk mempermudah perawat komunitas memfasilitasi pemberdayaan keluarga dengan usia lanjut serta penelitian lanjutan dengan jenis action research terkait dengan model perawatan usia lanjut di wilayah ini dengan mengaplikasikan keperawatan transkultural sebagai kerangka konsep penelitian agar diperoleh model perawatan yang untuk lanjut usia yang sesuai dengan budaya setempat (MR, JS, KN).

\section{Referensi}

Depkes RI. (2005). Pedoman pembinaan kesehatan usia lanjut bagi petugas kesehatan. Jakarta: Depkes RI.

Demartoto, A. (2003). Pelayanan berbasiskan keluarga dan relevansinya dengan kesejahteraan sosial lansia di perdesaan. Jurnal Penelitian dan Pendidikan, 3 (1), 41-56.

Dinkes Kab. Sidoarjo. (2004). Laporan pengelola-an program pembinaan usia lanjut (Tidak dipublikasikan). Dinas Kesehatan, Sidoarjo - Jawa Timur.

Erawati, N.K. (2002). Hubungan dukungan keluarga dan tingkat depresi pada lanjut usia di wilayah Puskesmas Denpasar Selatan Kota DenpasarBali (Laporan Penelitian, tidak dipublikasikan). Universitas Airlangga, Surabaya.

Friedman, M.M., Bowden, V.R., \& Jones, E.G. (2003). Family nursing: Research, theory, \& practice (5th Ed.). New Jersey: Prentice Hall.

Gallo, J.J., Reichel, W., \& Andersen, L.M. (1998). Buku saku gerontologi (Edisi 2). Jakarta: Penerbit Buku Kedokteran EGC.

Green, L. (1984). Modifying and developing health behavior. Annual Review of Public Health, 5, 215236. 
Hitchock, J.E., Schubert, P.E., \& Thomas, A. (1999). Community health nursing caring in action, California: An International Thompson Publishing Company.

Kuntjoro. (2002). Dukungan sosial pada lansia. Diperoleh dari http://www.e-psikologi.com.

Lueckenotte, A.G. (2000). Gerontologic nursing (2th Ed.). St. Louis: Mosby.

Miller, C. A. (2004). Nursing for wellness in older adults: Theory and practice (4th Ed.). Philadelphia: Lippincott.

Notoatmodjo, S. (2005). Promosi Kesehatan: Teori dan Aplikasi (Cetakan I). Jakarta: Penerbit Rineka Cipta.

Purwanto, H. (2002). Faktor-faktor yang berhubungan dengan perawatan yang dilakukan keluarga pada usia lanjut di Kecamatan Pesisir-Lamongan. Jurnal Penelitian Politeknik Kesehatan Surabaya, 1 (1), 33-39.

Riasmini, N. (2002). Analisis faktor-faktor yang berhubungan dengan kemampuan usia lanjut dalam melakukan aktivitas kehidupan seharihari di Kelurahan Palmeriam Kecamatan Matraman Jakarta Timur (Tesis master, tidak dipublikasikan). Program Pascasarjana Universitas Indonesia, Jakarta.
Rustika, \& Riyadina, W. (2000). Profil penduduk lanjut usia di Indonesia. Media Litbang Kesehatan, 10 (2), 16-26.

Sirait, \& Riyadina. (1999). Faktor-faktor yang mempengaruhi status kesehatan usia lanjut. Jurnal Epidemiologi Indonesia, 3(3), 21-30.

Sutarna, I.M. (2002). Alternatif model asuhan keperawatan keluarga dengan lanjut usia (Tesis master, tidak dipublikasikan). Program Pascasarjana Universitas Airlangga, Surabaya Jawa Timur.

Stanley, M., Blaire, K.A., \& Beare, P.G. (2005). Gerontological nursing: Promoting succesfull aging with older adults (3th Ed.). Philadelphia: F.A. Davis Company.

Sastroasmoro, \& Ismael. (2002). Dasa-dasar metodologi penelitian klinis (edisi 2). Jakarta: CV Sagung Seto.

Wiarsih, W. (1999). Peran keluarga dalam meningkatkan kesehatan jiwa lansia di rumah. Jurnal Keperawatan Indonesia, 2 (7), 254-257.

Yan Hao. (1998). Dependency of the chinese elderly: An exploration. Journal of the Australian Population Association, 15 (2), 171-186. 